\title{
Phakic Intraocular Lens Implantation After Deep Anterior Lamellar Keratoplasty: Retrospective Case Series Analysis With Long-Term Follow-Up
}

This article was published in the following Dove Press journal: Clinical Ophthalmology

\author{
Luísa Malheiro $\mathbb{D}^{1}$ \\ João Coelho (D) \\ Miguel Mesquita Neves (D) ${ }^{1,2}$ \\ Miguel Gomes (iD) 1,2 \\ Luís Oliveira (iD) ${ }^{1,2}$ \\ 'Ophthalmology Department, Hospital \\ De Santo António, Centro Hospitalar \\ Universitário Do Porto, Porto, Portugal; \\ ${ }^{2}$ Corneal Transplant Unit, Hospital De \\ Santo António, Centro Hospitalar \\ Universitário Do Porto, Porto, Portugal
}

Correspondence: Luísa Malheiro Ophthalmology Department, Hospital de Santo António, Centro Hospitalar Universitário do Porto, Porto 4099-00I, Portugal

Tel $+3519185584 \mid 4$

Email luisamalheiro90@gmail.com
Purpose: To report outcomes of phakic intraocular lens (IOL) implantation after deep anterior lamellar keratoplasty (DALK) to correct high ametropia.

Setting: Centro Hospitalar Universitário do Porto, Portugal.

Methods: Retrospective case series with 11 eyes submitted to phakic IOL implantation after DALK. Main outcomes measured were uncorrected and corrected distance visual acuity (UDVA and CDVA), refractive error components, tomographic parameters and endothelial cell density (ECD). The minimum follow-up was 3 years for all cases.

Results: Mean ECD loss was $8.7 \pm 6.7 \%$ at 1 year, $13.1 \pm 8.6 \%$ at 3 years $(n=11 ; p=0.016$, $\mathrm{p}=0.007$, respectively) and $14.0 \pm 20.4 \%$ at 5 years $(\mathrm{n}=5, \mathrm{p}=0.212)$. Mean logMAR UDVA increased from $1.27 \pm 0.90 \log$ MAR preoperatively to $0.16 \pm 0.15 \log$ MAR postoperatively $(p \leq 0.001)$ and no statistically significant differences were registered during follow-up. All patients gained at least 5 lines of UDVA. $54.5 \%$ of the eyes gained 1 line in CDVA postoperative and only one eye lost one CDVA line through follow-up. Efficacy and safety indexes at 1 and 3 years were 1.01-0.97 and 1.24-1.21, respectively. Mean spherical equivalent was reduced from $-7.84 \pm 4.63 \mathrm{D}$ preoperatively to $-1.05 \pm 1.07 \mathrm{D}$ postoperatively ( $p=0.001)$. Mean percentage of reduction in refractive cylinder and spherical error was 83.8 $\pm 15.8 \%$ and $73.1 \pm 31.5 \%$, respectively, $p \leq 0.001$ for both. In one eye there was a significantly gradual ECD loss over 5 years follow-up and the patient will be submitted to IOL explant. Conclusion: Phakic IOLs were effective for correction high ametropia after DALK, showing high efficacy and safety indexes with stability over time. However, it was registered a continuing endothelial cell loss postoperatively, which assumed to be higher than those reported in eyes without DALK.

Keywords: phakic intraocular lens, deep anterior lamellar keratoplasty, endothelial cell density, visual outcomes, refractive outcomes

\section{Introduction}

Deep anterior lamellar keratoplasty (DALK) is the gold-standard keratoplasty technique for the treatment of keratoconus and other anterior lamellar corneal pathology not affecting the endothelium. Risk of graft rejection, postoperative complications and late endothelial cell density (ECD) decay is reduced when compared to traditional penetrating keratoplasty (PK). Nevertheless, differences between visual acuity, refractive errors and corneal astigmatism following DALK or PK are similar. ${ }^{1-3}$

Postoperative uncorrected visual acuity after these procedures is often poor due to postoperative ametropia, especially high astigmatism. ${ }^{4}$ 
Several options can be considered for the management of postoperative ametropia, ranging from conservative solutions such as spectacles or contact lenses, to corneal refractive surgery and intraocular surgical procedures.

The presence of anisometropia can limit the use of spectacles. Rigid gas-permeable contact lenses are effective in a high percentage of patients, ${ }^{5}$ but topographical irregularities, dry eye, poor manual dexterity and lack of motivation make contact lenses' fitting a challenging process in some cases. Corneal refractive surgery with excimer laser photorefractive keratectomy (PRK) or LASIK can treat a great range of postoperative refractive error by corneal tissue ablation. However, the corneal graft thickness and the amount of ametropia and astigmatism suitable for correction limit the effectiveness of these procedures.

Intraocular surgical procedures with implantation of iris-fixated phakic intraocular lenses (IOLs) or posterior chamber IOLs ${ }^{6,7}$ can also be successfully used for surgical correction of high post-graft ametropia.

The Artisan ${ }^{\circledR}$ and Artiflex ${ }^{\circledR}$ lenses (Ophtec BV, Groningen, the Netherlands) are anterior chamber, iris-enclaved, phakic IOLs. These IOLs demonstrate reversibility, high optical quality, refractive predictability and stability. Some previous reports describe good postoperative results in the correction of ametropias after PK and DALK with these IOLs. ${ }^{8-12}$ However, to the best of our knowledge, there are few reports regarding long-term results of corneal ECD loss and visual and refractive outcomes of phakic IOL implantation in patients who had previously undergone DALK.

The aim of this study was to report the long-term clinical outcomes of a case series of patients with phakic
IOL implantation for correction of ametropia following DALK for keratoconus.

\section{Methods}

\section{Study Population}

Retrospective, noncomparative study with 11 eyes of 11 patients with keratoconus who underwent DALK with the big-bubble technique from February 2009 to June 2012 at Centro Hospitalar Universitário do Porto, Portugal. The patients were subsequently submitted to toric phakic IOL implantation for correction of ametropia.

All surgeries were performed by 2 surgeons, L.O and M.G, with extensive experience in the implantation of phakic IOLs.

Before phakic IOL implantation, the patients underwent routine ophthalmic examination, including manifest and cycloplegic refractions, evaluation of uncorrected distance visual acuity (UDVA) and distance corrected visual acuity (CDVA), slit-lamp examination, Goldmann applanation tonometry, gonioscopy, dilated fundus examination, corneal tomography and endothelial cell count.

Preoperatively, all the patients showed corneal graft transparency, normal status of the crystalline, anterior chamber depth (ACD) equal to or higher than $3.20 \mathrm{~mm}$, endothelial cell count higher than 1500 cells $/ \mathrm{mm}^{2}$ and a stable refractive status for at least 18 months. Table 1 summarizes the patients' details at baseline.

None of the patients had a history of recurrent or chronic uveitis, glaucoma, retinal pathologies or neurological eye diseases which could affect visual acuity.

This study was in accordance with the ethical principles for medical research involving human subjects

Table I Preoperative Parameters Of The Study Population

\begin{tabular}{|l|l|l|l|l|l|}
\hline Patient & $\begin{array}{l}\text { Age At The Time Of } \\
\text { IOL Implantation } \\
\text { (Years) }\end{array}$ & $\begin{array}{l}\text { Time Between DALK } \\
\text { And IOL Implantation } \\
\text { (Months) }\end{array}$ & $\begin{array}{l}\text { Preoperative } \\
\text { Subjective } \\
\text { Refraction (D) }\end{array}$ & $\begin{array}{l}\text { Preoperative ECD } \\
\left(\text { Cells } / \mathbf{m m}^{2}\right)\end{array}$ & $\begin{array}{l}\text { Preoperative } \\
\text { ACD (mm) }\end{array}$ \\
\hline 1 & 26 & 314 & $-5.0-4.5 \times 170^{\circ}$ & 2674 & 3.59 \\
2 & 27 & 25.9 & $-13.0-2.0 \times 150^{\circ}$ & 2404 & 3.75 \\
3 & 37 & 34.6 & $+2.5-6.5 \times 10^{\circ}$ & 1515 & 3.20 \\
4 & 34 & 42.0 & $-6.0 \times 30^{\circ}$ & 2320 & 3.25 \\
5 & 36 & 63.3 & $-7.5-10.0 \times 145^{\circ}$ & 2915 & 3.70 \\
6 & 42 & 39.3 & $-8.0-10.0 \times 90^{\circ}$ & 1835 & 4.11 \\
7 & 24 & 30.6 & $-4.0-5.0 \times 55^{\circ}$ & 1800 & 3.83 \\
8 & 18 & 30.2 & $-7.0-7.0 \times 145^{\circ}$ & 2703 & 3.88 \\
9 & 35 & 29.6 & $-1.0-8.5 \times 50^{\circ}$ & 2250 & 3.31 \\
10 & 23 & 35.9 & $-5.5-11.0 \times 10^{\circ}$ & 2994 & 3.70 \\
11 & 26 & 29.4 & $+3.0-11.0 \times 105^{\circ}$ & 2088 & 3.74 \\
\hline
\end{tabular}


(Helsinki Declaration) and was approved by the local ethics committee of Centro Hospitalar Universitário do Porto. Informed consent was obtained from each patient prior to surgical procedure.

\section{Outcomes Measures}

The main outcomes measures were UDVA, CDVA with manifest refraction, refractive sphere, refractive cylinder, refractive spherical equivalent (SE), topographic astigmatism, corneal thickness, ACD and corneal ECD. Calculation of safety index (mean postoperative CDVA/mean preoperative CDVA) and efficacy index (mean postoperative UDVA/ mean preoperative CDVA) of the procedure was conducted.

The incidence of intraoperative and postoperative complications of phakic IOLs implantation was also assessed.

For the current study, the outcomes were analysed preoperatively and at 1 and 3 years after surgery for all the patients $(n=11)$. In 5 patients, with a longer follow-up, the analysis was extended to 5 years after IOL implantation.

Corneal ECD was measured using specular microscope (Konan ${ }^{\circledR}$ Noncon Robo CA SP-8800) and the percentage of ECD loss per year was calculated. Topographic astigmatism, corneal thickness and ACD were measured using corneal Scheimpflug imaging (Oculus Wavelight Pentacam ${ }^{\circledR}$ ).

\section{Phakic IOLs Implanted}

The Artisan ${ }^{\circledR}$ phakic toric IOL (Ophtec BV, Groningen, the Netherlands) has a convex-concave toric optic. It is a single-piece lens with an overall size of $8.5 \mathrm{~mm}$ and is composed of polymethyl methacrylate (PMMA). It is irisclaw fixated and has a $5-\mathrm{mm}$ optical zone. The IOL is available in dioptric powers of -1.0 to -23.5 and +1.0 to +12.0 and in cylindrical powers of -1.0 to $-7.5 \mathrm{D}$. The Artifex ${ }^{\circledR}$ phakic toric IOL (Ophtec BV, Groningen, the Netherlands) is a foldable version of the Artisan ${ }^{\circledR}$ phakic IOL made of three pieces: a $6.0 \mathrm{~mm}$ similar convexconcave optic zone design, made of hydrophobic polysilicon, and two opposed haptics made of PMMA to enable fixation on the mid-peripheral iris. Overall length is $8 \mathrm{~mm}$. The IOL is available in dioptric powers of -1.0 to $-14.5 \mathrm{D}$ and in cylindrical powers of -1.0 to $-5.0 \mathrm{D}$.

The $\operatorname{Artisan}^{\circledR}$ phakic IOL was used when the refractive error could not be fully corrected by the Artiflex ${ }^{\circledR}$ lens.

The power calculation of the phakic IOL was obtained by Ophtec BV and approved by the surgeon. Refractive spherical error, refractive cylinder power, ACD and topographically derived keratometric dioptric values were inserted into the van der Heijde formula to calculate the dioptric power of the lens.

\section{Surgical Technique}

Previously to surgery, an iridectomy was made by a neodymium:YAG laser in all the eyes.

All surgeries were performed under general anesthesia. Pupils were constricted with pilocarpine $2 \%$ before surgery and the enclavation meridian was marked at the slit-lamp with a needle to avoid misalignments in relation to the cyclotorsion. For Artisan ${ }^{\circledR}$ lens, a $5 \mathrm{~mm}$ length clear corneal incision was created perpendicular to the axis of lens enclavation, followed by two stab incisions located close to the clear corneal incision, directed toward the enclavation sites. For Artiflex ${ }^{\circledR}$ lens it was used a clear corneal incision of $3.2 \mathrm{~mm}$. The anterior chamber was filled with viscoelastic (Provisc, Alcon Laboratories, Inc., Fort Worth, TX) and the lenses were slid into the anterior chamber, using a lens' forceps for Artisan ${ }^{\circledR}$ and a specially designed insertion spatula for Artiflex ${ }^{\circledR}$ (Operaid Artiflex ${ }^{\circledR}$ Implantation Spatula; Ophtec). Viscoelastic was re-injected and the lenses were placed in its proper position using a manipulator and fixed to the mid-peripheral iris with the enclavation needle, according to the alignment marks on the cornea. After, the viscoelastic was changed with balanced salt solution. Finally, the clear corneal incision was closed with $10-0$ nylon sutures and it was injected $1 \mathrm{mg} / 0.1 \mathrm{~mL}$ of cefuroxime sodium in the anterior chamber.

Postoperative care consisted of topical dexamethasone $0.2 \% 5$ times a day tapered in 3 weeks, topical fluoroquinolone 5 times a day for 2 weeks, topical nonsteroidal anti-inflammatory 5 times a day for 4 weeks and oral prednisolone $1 \mathrm{mg} / \mathrm{kg}$ in a defined tapering scheme during 2 weeks.

\section{Statistical Analysis}

UDVA and CDVA were recorded on a decimal scale and converted into logarithm of the minimum angle of resolution $(\log$ MAR) values to statistical analysis. The efficacy and safety indexes were calculated using a mean value expressed on decimal scale, before conversion. Statistical analysis was done using SPSS (version 24; SPSS Inc., Chicago, IL, USA). After checking the normality of data using the Shapiro-Wilk test, the Student's $t$-test for paired samples was used to compare preoperative and postoperative data when parametric analysis could be applied, and to compare it between consecutive postoperative visits. When non-parametric tests were required, the Wilcoxon ranked-sum test was used. Changes in corneal thickness, 
ACD and topographic astigmatism during follow-up were compared using repeated-measures two-way analysis of variance with Bonferroni correction. A $p$-value of less than 0.05 was considered statistically significant. All data were expressed as mean \pm SD.

\section{Results}

\section{Patient Population}

The study included 11 eyes of 11 patients ( 4 female, 7 male) with a mean age of $29 \pm 7$ years (range 17 to 42 years).

The mean time between DALK and toric phakic IOL implantation was $35.7 \pm 10.3$ months (range 25.9 to 63.2 months). All sutures were removed before IOL implantation. The refractive status was stable for at least 18 months before IOL implantation. The toric Artisan lens was implanted in 8 eyes (73\%) and the toric Artiflex lens in 3 eyes (27\%). All patients had a minimum follow-up of 3 years after IOL implantation. In 5 patients, the analysis of the outcomes was extended up to 5 years after IOL implantation ( 3 eyes with Artisan lens and 2 eyes with Artiflex lens). Figure 1 illustrates one of the eyes with an Artisan IOL at 1-year follow-up.

\section{Visual Acuity}

The mean logMAR UDVA and CDVA significantly increased from preoperative to 1 year postoperative $(n=11, p \leq 0.001$ for UDVA and $p=0.008$ ), as shown in Table 2.

During follow-up, no statistically significant differences were registered in UDVA and CDVA comparing to the values registered at 1 year postoperative $(p>0.05$, for all comparisons, Table 2). Postoperatively, all patients

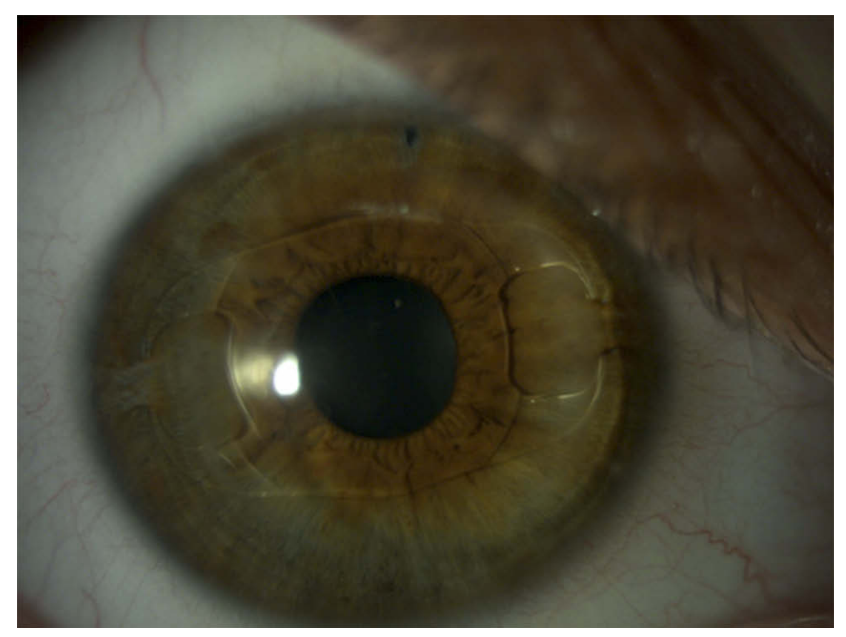

Figure I Postoperative slit-lamp photograph I year after toric Artisan phakic intraocular lens implantation in eye with previous DALK. gained at least 5 lines in UDVA (7.18 \pm 2.09 lines) and $63.6 \%$ of the eyes gained 2 or more lines in CDVA (Figures 2 and 3). During follow-up, only one eye lost 1 line in CDVA.

At 1 year of follow-up, $100 \%$ of the eyes had an UDVA equal or better than $0.30 \log$ MAR, and $45.5 \%$ an UDVA equal or better than $0.10 \log \mathrm{MAR}$, as compared with $0 \%$ preoperatively. At 3 years postoperative, an UDVA and a CDVA equal or better than 0.1 logMAR was registered in $45.4 \%$ and $81.8 \%$ of eyes, respectively.

The calculated efficacy index was 1.01, 0.97 and 1.02 at 1,3 and 5 years postoperatively, respectively. The calculated safety index was $1.24,1.21$ and 1.26 at 1,3 and 5 years, respectively.

\section{Refractive Outcome}

The mean sphere decreased from $-4.14 \pm 4.87 \mathrm{D}$ (range -13.00 to $+3.00 \mathrm{D}$ ) preoperative to $-0.55 \pm 0.82 \mathrm{D}$ (range -1.75 to $+1.00 \mathrm{D})$ at 1 year postoperative $(\mathrm{n}=11, p=0.033)$ and no statistically significant differences were registered during follow-up visits ( $\mathrm{n}=11, p=0.614$ for 3 years followup; $\mathrm{n}=5, p=0.847$ for 5 years follow-up). The percentage of reduction in spherical error was $73.1 \pm 31.5 \%$.

Mean refractive cylinder significantly decreased from $-7.41 \pm 3.61 \mathrm{D}$ (range -11.00 to $-2.00 \mathrm{D}$ ) preoperative to $-1.00 \pm 0.95 \mathrm{D}$ (range -2.50 to $0.0 \mathrm{D}$ ) at 1 year postoperative $(\mathrm{n}=11, p \leq 0.001)$. The mean percent reduction in refractive astigmatism was $83.8 \pm 15.8 \%$. No significant changes were observed in refractive cylinder during follow-up (Table 2). The distribution of the postoperative refractive astigmatism achieved is shown in Figure 4. At 3 years, the refractive cylinder was within $\pm 1.00 \mathrm{D}$ in $45.4 \%$ of eyes and within $\pm 2.00 \mathrm{D}$ in $81.8 \%$ of eyes.

The mean SE refraction decreased from $-8.02 \pm 4.63 \mathrm{D}$ (range -0.75 to $-14.00 \mathrm{D}$ ) preoperative to $-1.02 \pm 1.07 \mathrm{D}$ (range 0.0 to $-2.50 \mathrm{D})$ at 1 year postoperative $(n=11$, $\mathrm{p}=0.001)$. Figure 5 shows the SE accuracy 1 year after the procedure and Figure 6 illustrates the stability of SE during 3 years follow-up.

At 3 years, mean SE refraction was within $\pm 0.50 \mathrm{D}$ in $45.4 \%$ of eyes and within $\pm 1.50 \mathrm{D}$ in $63.6 \%$ of eyes.

Table 3 resumes the visual and refractive data of eyes submitted to Artisan and Artiflex IOLs implantation at 3 years follow-up.

\section{Endothelial Cell Count}

The endothelial cell loss, as compared with preoperative, was $8.7 \pm 6.7 \%(n=11), 13.1 \pm 8.6 \%(n=11)$ and $14.0 \pm 20.4 \%$ 
Table 2 Mean Preoperative And I, 3 And 5 Years Postoperative Results Of Toric Phakic IOL Implantation After DALK: Comparative Analysis

\begin{tabular}{|c|c|c|c|c|c|c|c|c|}
\hline \multirow[t]{2}{*}{ Outcomes } & \multicolumn{2}{|l|}{ UDVA } & \multicolumn{2}{|l|}{ CDVA } & \multicolumn{2}{|c|}{ Refractive Cylinder } & \multicolumn{2}{|c|}{ ECD (Cells $\left./ \mathrm{mm}^{2}\right)$} \\
\hline & Mean $\pm S D$ & p-Value & Mean $\pm S D$ & p-Value & Mean $\pm S D$ & p-Value & Mean士SD & p-Value \\
\hline $\begin{array}{l}\text { Preoperative vs I year } \\
\text { postoperative }(n=1 \mid)\end{array}$ & $\begin{array}{l}1.27 \pm 0.90 \text { vs } \\
0.16 \pm 0.15\end{array}$ & $\leq 0.001$ & $\begin{array}{l}0.16 \pm 0.14 \text { vs } \\
0.07 \pm 0.09\end{array}$ & 0.008 & $\begin{array}{l}-7.4 I \pm 3.6 I \text { vs } \\
-1.00 \pm 0.95\end{array}$ & $\leq 0.001$ & $\begin{array}{l}2318 \pm 457 \text { vs } \\
2108 \pm 547\end{array}$ & 0.020 \\
\hline $\begin{array}{l}\text { Preoperative vs } 3 \text { year } \\
\text { postoperative }(n=1 \mathrm{I})\end{array}$ & $\begin{array}{l}1.27 \pm 0.90 \text { vs } \\
0.22 \pm 0.17\end{array}$ & $\leq 0.001$ & $\begin{array}{l}0.16 \pm 0.14 \text { vs } \\
0.08 \pm 0.10\end{array}$ & 0.011 & $\begin{array}{l}-7.4| \pm 3.6| \text { vs } \\
-1.63 \pm 0.90\end{array}$ & $\leq 0.001$ & $\begin{array}{l}2318 \pm 457 \text { vs } \\
1961 \pm 574\end{array}$ & 0.007 \\
\hline $\begin{array}{l}\text { Preoperative vs } 5 \text { year } \\
\text { postoperative }(n=5)\end{array}$ & $\begin{array}{l}1.30 \pm 0.0 \text { vs } \\
0.12 \pm 0.11\end{array}$ & $\leq 0.001$ & $\begin{array}{l}0.14 \pm 0.09 \text { vs } \\
0.02 \pm 0.04\end{array}$ & 0.033 & $\begin{array}{l}-6.75 \pm 2.04 \text { vs } \\
-0.85 \pm 0.49\end{array}$ & $\leq 0.001$ & $\begin{array}{l}2105 \pm 438 \text { vs } \\
1768 \pm 548\end{array}$ & 0.137 \\
\hline $\begin{array}{l}\text { I year postoperative vs } 3 \\
\text { years postoperative }(n=I I)\end{array}$ & $\begin{array}{l}0.16 \pm 0.15 \text { vs } \\
0.22 \pm 0.17\end{array}$ & 0.364 & $\begin{array}{l}0.07 \pm 0.09 \text { vs } \\
0.08 \pm 0.10\end{array}$ & $0.34 I$ & $\begin{array}{l}-1.00 \pm 0.95 \text { vs } \\
-1.63 \pm 0.90\end{array}$ & 0.006 & $\begin{array}{l}2108 \pm 547 \text { vs } \\
1961 \pm 574\end{array}$ & 0.523 \\
\hline $\begin{array}{l}\text { I year postoperative vs } 5 \\
\text { years postoperative }(n=5)\end{array}$ & $\begin{array}{l}0.16 \pm 0.21 \text { vs } \\
0.12 \pm 0.11\end{array}$ & 0.757 & $\begin{array}{l}0.02 \pm 0.04 \text { vs } \\
0.03 \pm 0.07\end{array}$ & 0.945 & $\begin{array}{l}-0.37 \pm 0.40 \text { vs } \\
-0.85 \pm 0.49\end{array}$ & 0.102 & $\begin{array}{l}2018 \pm 180 \text { vs } \\
1768 \pm 548\end{array}$ & 0.090 \\
\hline $\begin{array}{l}3 \text { years postoperative vs } 5 \\
\text { years postoperative }(n=5)\end{array}$ & $\begin{array}{l}0.14 \pm 0.09 \text { vs } \\
0.12 \pm 0.11\end{array}$ & 0.317 & $\begin{array}{l}0.04 \pm 0.05 \text { vs } \\
0.03 \pm 0.07\end{array}$ & 0.317 & $\begin{array}{l}-0.83 \pm 0.44 \text { vs } \\
-0.85 \pm 0.49\end{array}$ & 0.921 & $\begin{array}{l}|840 \pm 59| \text { vs } \\
\mid 768 \pm 548\end{array}$ & 0.255 \\
\hline
\end{tabular}

Note: Significant values are shown in bold.

$(\mathrm{n}=5)$ at 1 year $(p=0.020), 3$ years $(p=0.007)$ and 5 years postoperatively $(p=0.137)$, respectively.

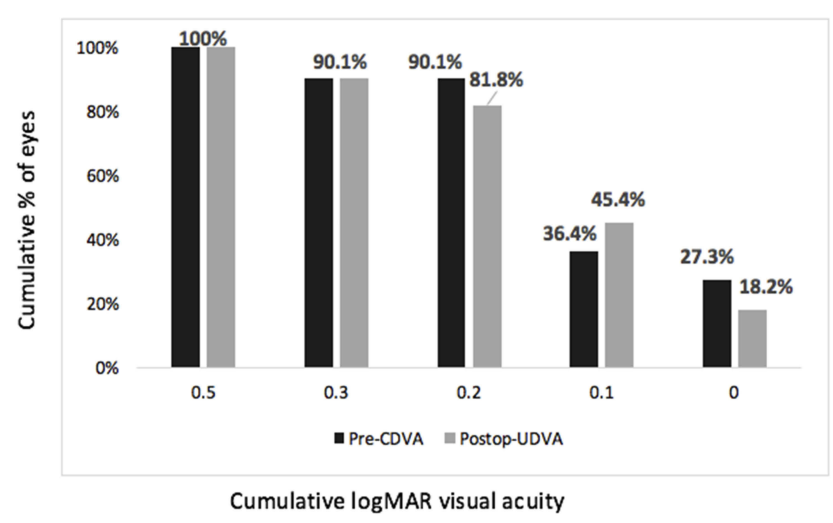

Figure 2 Cumulative uncorrected distance visual acuity I year after surgery $(\mathrm{n}=\mathrm{II})$.

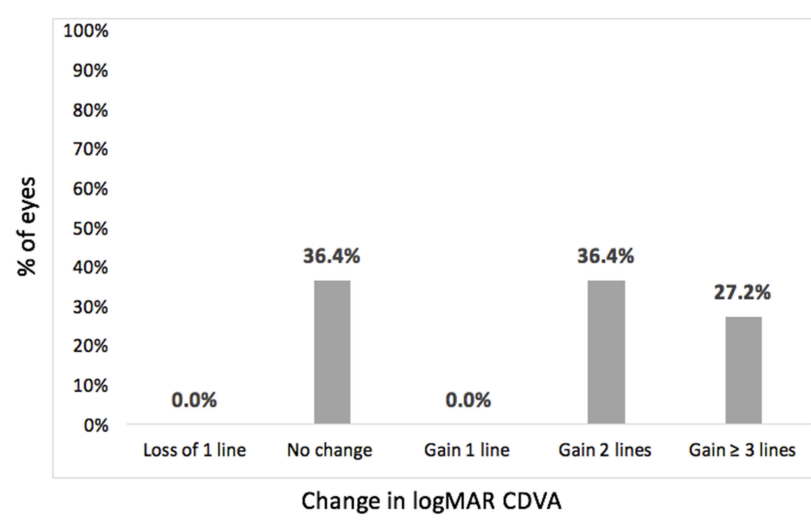

Figure 3 Change in corrected distance visual acuity I year after surgery $(n=11)$.
It was registered a progressive decrease in ECD over time in operated eyes. The decline in ECD between 1 to 3 years and 3 to 5 years of follow-up was not statistically significant (Table 2).

\section{Corneal Thickness, ACD And Topographic Astigmatism}

There were no statistically significant differences in corneal thickness, ACD and topographic astigmatism over time (Table 4).

\section{Intraoperative And Postoperative Complications Of TICL Implantation}

No severe intraoperative complications were registered. None of the eyes included developed ocular hypertension, pupillary block, acute angle-closure glaucoma or episodes of graft rejection. One of the patients (patient 3, male, 37 years old at the time of IOL implantation) had registered an important decrease in ECD and ACD over the 5 years' follow-up. This patient had the lowest ECD and ACD preoperatively. Before Artisan Iens implantation, the ECD was 1515 cells/ $\mathrm{mm}^{2}$ and ACD was $3.20 \mathrm{~mm}$. One year after surgery, the ECD had decreased to $1001 \mathrm{cells} / \mathrm{mm}^{2}$. At this time, the patient was proposed to IOL explantation but had refused the intervention. The patient was clarified about the risk of endothelial decompensation and advised not to rub the eye. Two years after surgery, the ECD decreased to 851 cells $/ \mathrm{mm}^{2}$ 


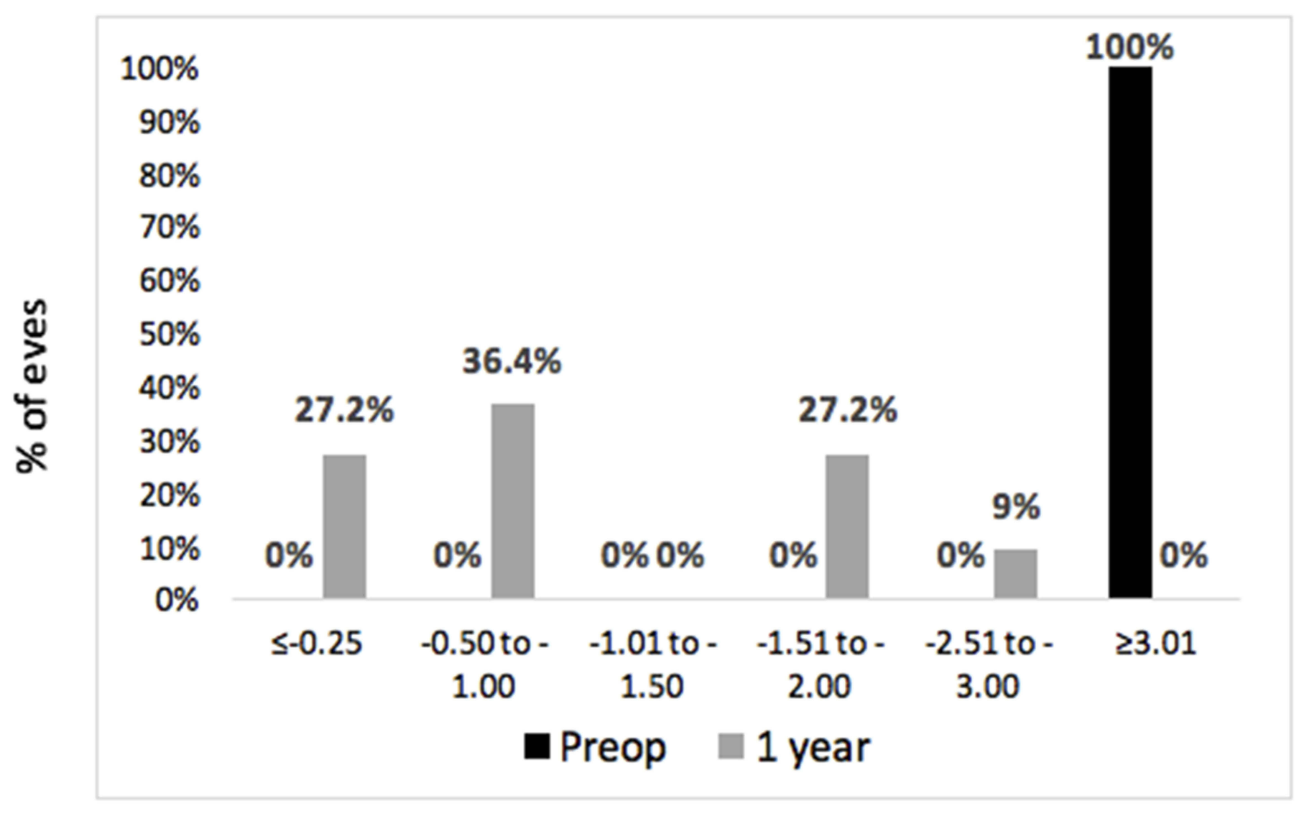

$\leq 0.50: 54.5 \%$

$\leq 1.00 \mathrm{D}: 63.6 \%$

\section{Refractive cylinder (D)}

Figure 4 Preoperative and I year postoperative refractive cylinder $(n=I I)$ in diopters.

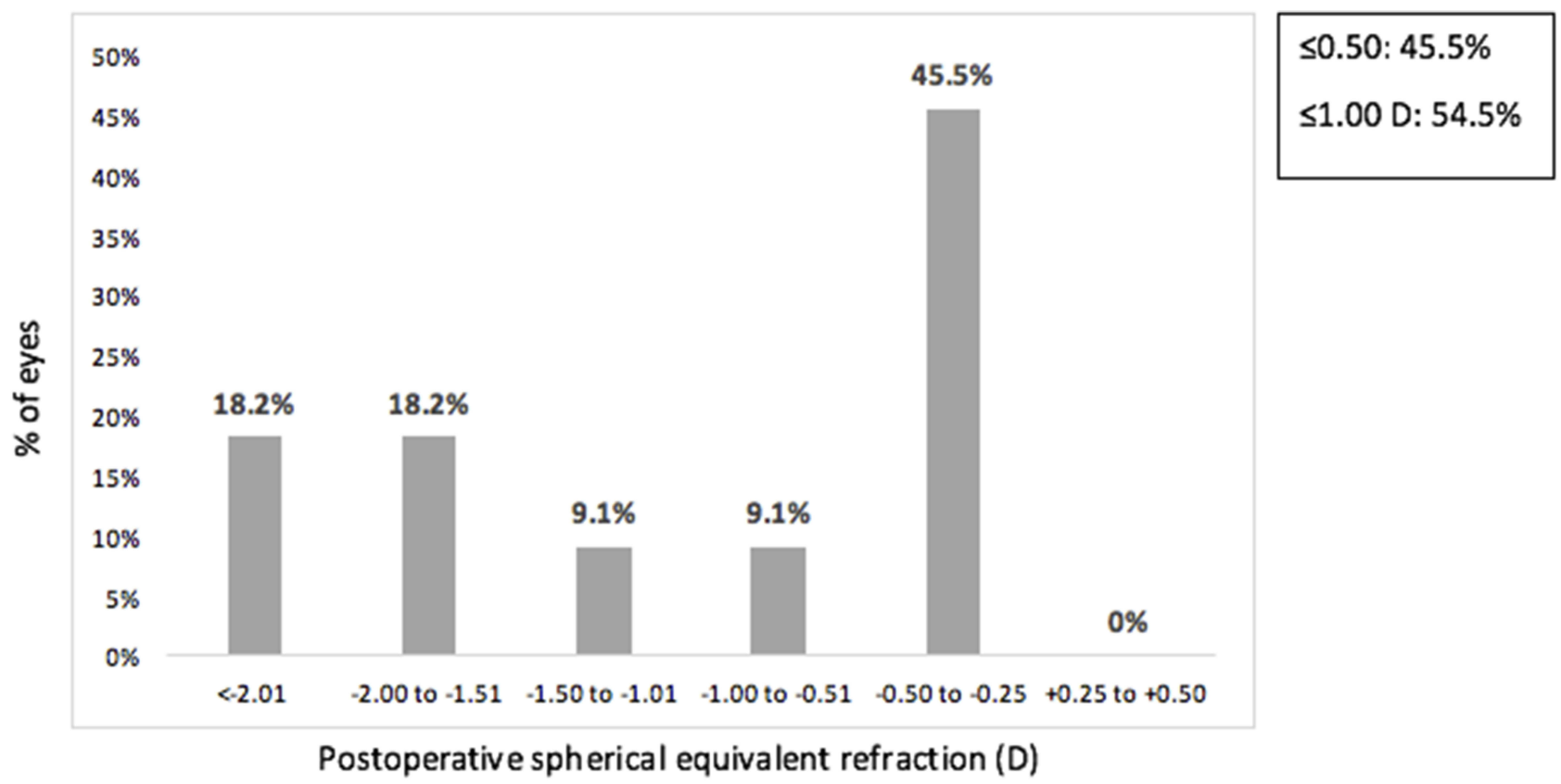

Figure 5 Spherical equivalent refractive accuracy I year after surgery $(n=\mid I)$.

and at 3 years follow-up, it was registered an ECD of 840 cells $/ \mathrm{mm}^{2}$ and an ACD of $2.94 \mathrm{~mm}$. During this time, the patient continued refusing explantation of the IOL, so was kept in close monitoring and aware of the risk of sudden endothelial decompensation. At the last appointment, it was recorded an ECD of 835 cells $/ \mathrm{mm}^{2}$ and an ACD of $2.91 \mathrm{~mm}$. The patient maintained a transparent graft and an UDVA of $0.0 \operatorname{logMAR}$, though will be soon submitted to IOL explantation combined with phacoemulsification cataract surgery with toric IOL implantation in the capsular bag. 


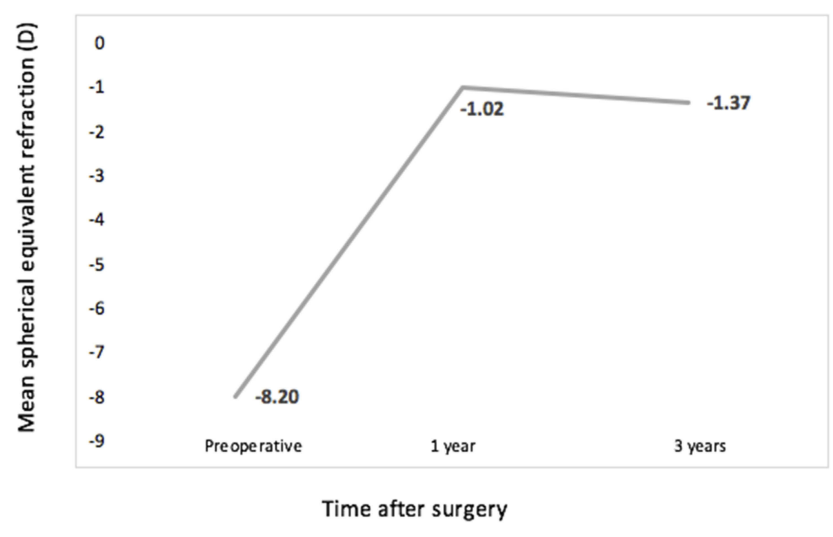

Figure 6 Stability of spherical equivalent during follow-up.

\section{Discussion}

Several surgical options to correct refractive errors after DALK have been reported in the literature, such as PRK, ${ }^{13,14}$ LASIK, $^{15,16}$ small incision lenticule extraction ${ }^{17}$ and corneal relaxing incisions. ${ }^{18}$ In addition, phakic IOLs implantation have also been satisfactorily used for visual rehabilitation after DALK in more recent reports. ${ }^{7,10-12}$

Tiveron et $\mathrm{al}^{12}$ reported the efficacy of toric phakic IOLs after DALK in 24 eyes (17 with implantation of Artiflex lens and 7 with Artisan lens) with a follow-up of 1 year. Comparing to this study, we obtained a higher safety and efficacy indexes (1.24 vs 1.00 and 1.01 vs 0.93 , respectively) at 1 year. Moreover, in our case series the values of these indexes slightly decreased during 3 and 5 years of follow-up, so these IOLs proved to be a safety and effective procedure for visual rehabilitation with stability over time.

The first two case reports of implantation of Artisan IOL to correct ametropia ${ }^{10}$ and high astigmatism after DALK ${ }^{11}$ revealed a significant improvement in UDVA postoperatively, with all the 3 patients showing an UDVA and a CDVA of $0.1 \operatorname{logMAR}$ or better at 1 year of follow-up. In this current study, the 11 patients gained at least 5 lines of UDVA postoperatively, $63.6 \%$ of the eyes improved two or more lines in CDVA at 1 year of follow-up and only one eye lost one line in CDVA throughout follow-up.

Acar et $\mathrm{al}^{15}$ also described a significant improvement in UDVA with LASIK after DALK, without eyes losing CDVA lines. Recently, Sorkin et $\mathrm{al}^{14}$ reported a significant improvement in CDVA and UDVA in 34 eyes submitted to PRK postkeratoplasty. Comparing to phakic IOLs, corneal ablation procedures carry a relatively high rate of

Table 3 Visual And Refractive Outcomes At 3 Years Follow-Up

\begin{tabular}{|l|l|l|l|l|l|l|l|}
\hline Patient & $\begin{array}{l}\text { Pre-UDVA } \\
\text { (logMAR) }\end{array}$ & $\begin{array}{l}\text { Pre-BDVA } \\
\text { (logMAR) }\end{array}$ & $\begin{array}{l}\text { Preoperative } \\
\text { Refraction (D) }\end{array}$ & $\begin{array}{l}\text { Type Of Toric } \\
\text { Phakic IOL } \\
\text { Implanted }\end{array}$ & $\begin{array}{l}\text { 3 Years Post- } \\
\text { UDVA } \\
\text { (logMAR) }\end{array}$ & $\begin{array}{l}\text { 3 Years Post- } \\
\text { BDVA } \\
\text { (logMAR) }\end{array}$ & $\begin{array}{l}\text { 3 Years } \\
\text { Postoperative } \\
\text { Refraction (D) }\end{array}$ \\
\hline 1 & 1.30 & 0.20 & $-5.0-4.5 \times 170^{\circ}$ & Artiflex & 0.30 & 0.10 & $-0.75-2.50 \times 100^{\circ}$ \\
2 & 1.30 & 0.00 & $-13.0-2.0 \times 150^{\circ}$ & Artisan & 0.00 & 0.00 & $-0.50 \times 170^{\circ}$ \\
3 & 1.30 & 0.00 & $+2.5-6.5 \times 10^{\circ}$ & Artisan & 0.00 & 0.00 & $-0.50 \times 20^{\circ}$ \\
4 & 1.30 & 0.10 & $-6.0 \times 30^{\circ}$ & Artisan & 0.20 & 0.10 & $-1.00-2.00 \times 110^{\circ}$ \\
5 & 1.30 & 0.20 & $-7.5-10.0 \times 145^{\circ}$ & Artisan & 0.20 & 0.10 & $-2.00-2.00 \times 55^{\circ}$ \\
6 & 1.30 & 0.50 & $-8.0-10.0 \times 90^{\circ}$ & Artisan & 0.50 & 0.30 & $-1.00-1.00 \times 70^{\circ}$ \\
7 & 1.30 & 0.20 & $-4.0-5.0 \times 55^{\circ}$ & Artiflex & 0.20 & 0.00 & $-1.50 \times 35^{\circ}$ \\
8 & 1.30 & 0.20 & $-7.0-7.0 \times 145^{\circ}$ & Artiflex & 0.20 & 0.10 & $-1.25 \times 110^{\circ}$ \\
9 & 1.30 & 0.20 & $-1.0-8.5 \times 50^{\circ}$ & Artisan & 0.20 & 0.00 & $-1.00-0.50 \times 40^{\circ}$ \\
10 & 1.30 & 0.00 & $-5.5-11.0 \times 10^{\circ}$ & Artisan & 0.50 & 0.00 & $-3.00-0.75 \times 0^{\circ}$ \\
11 & 1.00 & 0.20 & $+3.0-11.0 \times 105^{\circ}$ & Artisan & 0.20 & 0.10 & $+1.00-2.50 \times 100^{\circ}$ \\
\hline
\end{tabular}

Table 4 Differences In Corneal Thickness, Anterior Chamber Depth And Topographic Astigmatism During Follow-Up

\begin{tabular}{|l|l|l|l|l|l|l|}
\hline & Preoperative & I Year (n=II) & 3 Years (n=II) & $\mathbf{5}$ Years (n=5) & $\begin{array}{l}\text { p-Value 3 Years } \\
\text { Follow-Up }(\mathbf{n}=1 \text { I) }\end{array}$ & $\begin{array}{l}\text { p-Value } 5 \text { Years } \\
\text { Follow-Up (n=5) }\end{array}$ \\
\hline Corneal thickness (um) & $518 \pm 56.1$ & $515 \pm 48.2$ & $507 \pm 52.8$ & $536 \pm 22.3$ & 0.661 & 0.847 \\
\hline ACD (mm) & $3.62 \pm 0.33$ & $3.53 \pm 0.35$ & $3.48 \pm 0.26$ & $3.48 \pm 0.4 I$ & 0.154 & 0.528 \\
\hline $\begin{array}{l}\text { Topographic } \\
\text { astigmatism (D) }\end{array}$ & $6.82 \pm 2.70$ & $5.88 \pm 3.49$ & $5.49 \pm 3.95$ & $5.24 \pm 2.10$ & 0.387 & 0.089 \\
\hline
\end{tabular}


complications, such as corneal graft haze and regression of treatment, offer less predictable results and may not fully correct large degrees of spherical and astigmatic refractive errors. $^{8,19-23}$

The magnitude of the baseline spherical error (range +3.0 to $-13.0 \mathrm{D}$ ) and cylindrical error (range -2.0 to $-11.0 \mathrm{D}$ ) of this case series reflect the wide field of power range provided by phakic IOLs. These baseline refractive values were much higher than those revealed in most of the reports of LASIK postkeratoplasty, including DALK. ${ }^{15,16}$ Moreover, the percentage of reduction in refractive astigmatism $(83.8 \pm 15.8 \%)$ was higher when compared to LASIK after keratoplastly, which varies from $48 \%$ to $88 \%$ in different reports of the literature. $^{19-24}$

Concerning stability of the surgical procedure, there were no significant changes in refractive spherical, cylinder and SE values from 1 to 3 years and 5 years of follow-up. Also in a prospective noncomparative study with Artisan toric IOL implantation for the correction of astigmatism and anisometropia after $\mathrm{PK}$, Tahzib et $\mathrm{al}^{8}$ revealed a reduction in the refractive cylinder and sphere of $88.8 \pm 29.5 \%$ and $103.6 \% \pm 33.0$, respectively, with the stability of the values achieved from 6 months postoperatively to 3 years of follow-up.

In this case series we presented an ECD loss of $8.7 \pm 6.7 \%$ $(\mathrm{n}=11), 13.1 \pm 8.6 \%(\mathrm{n}=11)$ and $14.0 \pm 20.4 \%(\mathrm{n}=5)(p=0.137)$ at 1, 3 and 5 years of follow-up, respectively. The percentage of ECD loss at 1 year was slightly higher than the published by Tiveron et al. ${ }^{12}$ However, these results were favorable when compared to those reported by Tahzib et $\mathrm{al}^{8}$ in eyes with Artisan IOL after PK (Table 5). This could be explained by the fact that ECD decay is higher after PK comparing to DALK, as shown in several studies comparing both techniques. $^{2,3,25}$ In our center, the mean ECD loss after DALK was $5.3 \% \pm 4.8 \%$ at 1 year after surgery. Comparing to eyes without keratoplasty, the ECD loss in the current series is higher than the revealed by other studies for $\operatorname{Artisan}^{26-28}$ and Artiflex IOLs ${ }^{29,30}$ (Table 5).

Despite our small sample size, we observed a progressive endothelial cell loss at each time point as compared with preoperative cell density values. The observed mean ECD loss could be explained by the lens itself, by the normal ECD loss after DALK or by the combination of both. Nevertheless, it was not registered a significantly loss between 1 year postoperatively to 3 and 5 years. It is consistent with other reports which describe a more significant decline in ECD during the first 12-24 months after phakic IOLs implantation. ${ }^{31,32}$

In this case series, there was one patient who revealed a significant decrease in ECD and ACD over time, reaching values lower than 1000 cells $/ \mathrm{mm}^{2}$ and $3.00 \mathrm{~mm}$, respectively. It should be noted that the preoperative

Table 5 Summary Of Authors And Their Study' Results For ECD Loss After Keratoplasty And After Phakic IOLs Implantation In Eyes With And Without Keratoplasty

\begin{tabular}{|c|c|c|c|c|}
\hline Author, Year & Technique & $\begin{array}{l}\text { Sample Size } \\
\text { ( } n=\text { Eyes) }\end{array}$ & Country & ECD Loss \\
\hline Tiveron et al, ${ }^{12} 2017$ & Artisan and Artiflex IOLs after DALK & 24 & Spain & I year: $6.10 \%$ \\
\hline Tahzib et al, ${ }^{8} 2006$ & Artisan IOL after PK & 34 & The Netherlands & $\begin{array}{l}\text { I year: } 21.2 \%(n=34) \\
3 \text { years: } 30.4 \%(n=\mid 8)\end{array}$ \\
\hline Cheng, ${ }^{25} 2011$ & PK vs DALK & 56 & The Netherlands & I year: $27.7 \%$ PK vs $12.9 \%$ DALK \\
\hline Pop, $^{26} 2004$ & Artisan IOL without keratoplasty & 765 & Canada & I year: $0.87 \%$ \\
\hline Hashemi, ${ }^{27} 2013$ & Artisan IOL without keratoplasty & 53 & Iran & I year: $3.04 \%$ \\
\hline Silva, ${ }^{28} 2008$ & Artisan IOL without keratoplasty & 26 & USA & 5 years: $14.0 \%$ \\
\hline Guerin et $\mathrm{al}^{29} 2014$ & Artiflex IOL without keratoplasty & 28 & Ireland & I year: $6.17 \%$ \\
\hline Jonker, ${ }^{30} 2018$ & Artiflex IOL without keratoplasty & 188 & The Netherlands & 5 years: $10.2 \%$ \\
\hline Our Center, 2018 & DALK & 47 & Portugal & I year: $5.3 \%$ \\
\hline Current study, 2019 & Toric phakic IOLs after DALK & 11 & Portugal & $\begin{array}{l}\text { I year: } 8.7 \%(n=I I) \\
3 \text { years: } 13.1 \%(n=11) \\
5 \text { years: } 14.0 \%(n=5)\end{array}$ \\
\hline
\end{tabular}


values of ECD and ACD of this patient were the lowest of the sample. The decision to implant phakic IOLs in patients with preoperative endothelial cell counts lower than those recommended by Ophtec BV is based on the fact that, for these patients, with low BCVA due to high ametropias after corneal transplantation, the implantation of phakic IOLs is not considered a premium refractive surgery. Instead, the main purpose of the procedure is to try to provide a better visual acuity in patients who had already tried other less invasive refractive options, without success. This decision is made together with the patient after carefully explaining and discussing all the complications of the surgery.

The patient will be submitted to IOL explantation combined with cataract surgery, that, still, highlights one of the advantages of phakic IOLs implantation, which is the reversibility of the procedure, in contrast to corneal ablation procedures.

To the best of our knowledge, this is the first case series describing long-term results of toric phakic IOLs after DALK. We demonstrate that these IOLs are an effective and stable procedure for management high ametropia after DALK. However, we observed a continuing endothelial cell loss postoperatively, which assumed to be higher than those reported in eyes with phakic IOLs implantation without DALK. Additional long-term analysis with larger samples are needed to confirm these results and for them to be used as guidance for clinical practice.

\section{Disclosure}

The authors have no conflict of interest to report and have not received any financial support for the research provided.

\section{References}

1. Oh BL, Kim MK, Wee WR. Comparison of clinical outcomes of samesize grafting between deep anterior lamellar keratoplasty and penetrating keratoplasty for keratoconus. Korean J Ophthalmol. 2013;27:322330. doi:10.3341/kjo.2013.27.5.322

2. Keane M, Coster D, Ziaei M, Williams K. Deep anterior lamellar keratoplasty versus penetrating keratoplasty for treating keratoconus. Cochrane Database Syst Rev. 2014;7:CD009700.

3. Liu H, Chen Y, Wang P, et al. Efficacy and safety of deep anterior lamellar keratoplasty vs. penetrating keratoplasty for keratoconus: a meta-analysis. PLoS One. 2015;10:e113332. doi:10.1371/journal. pone. 0113332

4. Langenbucher A, Naumann GO, Seitz B. Spontaneous long-term changes of corneal power and astigmatism after suture removal after penetrating keratoplasty using a regression model. Am J Ophthalmol. 2005;140:29-34. doi:10.1016/j.ajo.2005.01.038

5. Geerards AJ, Vreugdenhil W, Khazen A. Incidence of rigid gas-permeable contact lens wear after keratoplasty for keratoconus. Eye Contact Lens. 2006;32(4):207-210. doi:10.1097/01.icl.0000191953.84449.d6
6. Akcay L, Kaplan AT, Kandemir B, et al. Toric intraocular Collamer lens for high myopic astigmatism after penetrating keratoplasty. $J$ Cataract Refract Surg. 2009;35:2161-2163. doi:10.1016/j.jcrs.2009.06.034

7. Qin Q, Yang L, He Z, Huang Z. Clinical application of TICL implantation for ametropia following deep anterior lamellar keratoplasty for keratoconus: a CONSORT-compliant article. Medicine (Baltimore). 2017;96:e6118. doi:10.1097/MD.0000000000006118

8. Tahzib NG, Cheng YY, Nuijts RM. Three-year follow-up analysis of Artisan toric lens implantation for correction of postkera- toplasty ametropia in phakic and pseudophakic eyes. Ophthalmology. 2006;113:976-984. doi:10.1016/j.ophtha.2006.02.025

9. Moshirfar M, Barsam CA, Parker JW. Implantation of an Artisan phakic intraocular lens for the correction of high myopia after penetrating keratoplasty. J Cataract Refract Surg. 2004;30:1578-1581. doi:10.1016/j.jcrs.2003.12.059

10. Georgoudis P, Tappin MJ. Artisan phakic IOL for the correction of ametropia after deep anterior lamellar keratoplasty. J Refract Surg. 2010;26:87. doi:10.3928/1081597X-20100121-03

11. Al-Dreihi MG, Louka BI, Anbari AA. Artisan iris-fixated toric phakic intraocular lens for the correction of astigmatism after deep anterior lamellar keratoplasty. Digit J Ophthalmol. 2013;19:39-41. doi:10.5693/djo.02.2013.04.001

12. Tiveron MC, Alió Del Barrio JL, Kara-Junio N, et al. Outcomes of toric iris-claw phakic intraocular lens implantation after deep anterior lamellar keratoplasty for keratoconus. J Refract Surg. 2017;33:538544. doi:10.3928/1081597X-20170616-02

13. Leccisotti A. Photorefractive keratectomy with mitomycin $\mathrm{C}$ after deep anterior lamellar keratoplasty for keratoconus. Cornea. 2008;27(4):417-420. doi:10.1097/ICO.0b013e318164e4b8

14. Sorkin N, Einan-Lifshitz A, Abelson A, et al. Stepwise guided photorefractive keratectomy in treatment of irregular astigmatism after penetranting keratoplasty and deep anterior lamellar keratoplasty. Cornea. 2017;36:1308-1315. doi:10.1097/ICO.0000000000001359

15. Acar BT, Utine CA, Acar S, Ciftci F. Laser in situ keratomileusis to manage refractive errors after deep anterior lamellar keratoplasty. J Cataract Refract Surg. 2012;38:1020-1027. doi:10.1016/ j.jcrs.2011.12.034

16. Balestrazzi A, Menicacci F, Cartocci G, Menicacci F, Michieletto P, Balestrazzi E. Femtosecond laser-assisted in situ keratomileusis for the correction of residual ametropia after deep anterior lamellar keratoplasty: a pilot investigation. Eye. 2017;31:1168-1175. doi:10.1038/eye.2017.44

17. Mastropasqua L, Calienn R, Lanzini M, Nubile M. Small incision lenticule extraction after deep anterior lamellar keratoplasty. $J$ Refract Surg. 2015;31:634-637. doi:10.3928/1081597X-20150820-10

18. Javadi MA, Feizi S, Mirbabaee F, Rastegarpour A. Relaxing incisions combined with adjustment sutures for post-deep anterior lamellar keratoplastyastigmatism in keratoconus. Cornea. 2009;28:11301134. doi:10.1097/ICO.0b013e3181a3c400

19. Rashad KM. Laser in situ keratomileusis for correction of high astigmatism after penetrating keratoplasty. $J$ Refract Surg. 2000;16:701-710.

20. Vajpayee RB, Sharma N, Sinha R, Bhartiya P, Titiyal JS, Tandon R. Laser in-situ keratomileusis after penetrating keratoplasty. Surv Ophthalmol. 2003;48:503-514. doi:10.1016/s0039-6257(03)00085-7

21. Donnenfeld ED, Solomon R, Biser S. Laser in situ keratomileusis after penetrating keratoplasty. Int Ophthalmol Clin. 2002;42:67-87. doi:10.1097/00004397-200210000-00008

22. Malecha MA, Holland EJ. Correction of myopia and astigmatism after penetrating keratoplasty with laser in situ keratomileusis. Cornea. 2002;21:564-569. doi:10.1097/00003226-200208000-00006

23. Barraquer CC, Rodriguez-Barraquer T. Five-year results of laser insitu keratomileusis (LASIK) after penetrating keratoplasty. Cornea. 2004;23:243-248. doi:10.1097/00003226-200404000-00005

24. Kwitko S, Marinho DR, Rymer S, Ramos Filho S. Laser in situ keratomileusis after penetrating keratoplasty. $J$ Cataract Refract Surg. 2001;27:374-379. doi:10.1016/S0886-3350(00)00642-8 
25. Cheng YY, Visser N, Schouten JS, et al. Endothelial cell loss and visual outcome of deep anterior lamellar keratoplasty versus penetrating keratoplasty: a randomized multicenter clinical trial. Ophthalmology. 2011;118:302. doi:10.1016/j.ophtha.2010.06.005

26. Pop M, Payette Y. Initial results of endothelial cell counts after Artisan lens for phakic eyes. An evaluation of the United States Food and Drug Administration Ophtec Study. Ophthalmology. 2004;111:309-317. doi:10.1016/j.ophtha.2004.04.014

27. Hashemi H, Taherzadeh M, Khabazkhoob M. Correction of high myopia with foldable Artiflex Phakic intraocular lenses: 1 year follow-up results. Acta Med Iran. 2013;51:620-625.

28. Silva RA, Jain A, Manche EE. Prospective long-term evaluation of the efficacy, safety, and stability of the phakic intraocular lens for high myopia. Arch Ophthalmol. 2008;126:775-781. doi:10.1001/ archopht.126.6.775
29. Guerin MB, Treacy MP, O’Keeffe M. Twelve-month follow-up of the Artiflex toric phakic intraocular lens. Eur J Ophthalmol. 2014;24:10 13. doi:10.5301/ejo.5000298

30. Jonker SMR, Berendschot TTTJM, Ronden AE, Saelens IEY, Bauer NJC, Nuijts RMMA. Five- year endothelial cell loss after implantation with Artiflex Myopia and Artiflex Toric Phakic intraocular lenses. Am J Ophthalmol. 2018;194:110-119. doi:10.1016/j.ajo. 2018.07.015

31. Budo C, Hessloehl JC, Izak M. Multicenter study of the Artisan phakic intraocular lens. J Cataract Refract Surg. 2000;26:11631171. doi:10.1016/s0886-3350(00)00465-x

32. Benedetti S, Casamenti V, Benedetti M. Long-term endothelial changes in phakic eyes after Artisan intraocular lens implantation to correct myopia: five-year study. $J$ Cataract Refract Surg. 2007;33:784-790. doi:10.1016/j.jcrs.2007.01.037
Clinical Ophthalmology

\section{Publish your work in this journal}

Clinical Ophthalmology is an international, peer-reviewed journal covering all subspecialties within ophthalmology. Key topics include: Optometry; Visual science; Pharmacology and drug therapy in eye diseases; Basic Sciences; Primary and Secondary eye care; Patient Safety and Quality of Care Improvements. This journal is indexed on PubMed

\section{Dovepress}

Central and CAS, and is the official journal of The Society of Clinical Ophthalmology (SCO). The manuscript management system is completely online and includes a very quick and fair peer-review system, which is all easy to use. Visit http://www.dovepress.com/ testimonials.php to read real quotes from published authors. 